\title{
AS COORDENADAS POLÍTICAS DA ELECCIÓN DA LINGUA DE COMUNICACIÓN DA IGREXA CATÓLICA EN GALICIA E CASUBIA
}

Maria Boguszewicz

Universidade de Varsovia (Polonia)

doi:10.17075/tucmeg.2015.012 
O presente artigo trata de dous elementos que son fundamentais para todas as culturas: a lingua e a relixión. A lingua non é só un dos vehículos da comunicación senón todo un sistema que estrutura o noso modo de percibir o mundo. A relixión é a expresión do sacrum e a Igrexa é a institucionalización da relixión na sociedade. A lingua ten unha importancia extraordinaria na práctica relixiosa. A Igrexa católica tivo a conciencia do peso do elemento lingüístico na súa ensinanza. Houbo dous momentos especialmente importantes neste sentido:

o Concilio de Trento (1545-1563) e o Concilio Vaticano II (CVII) (1962-1965). No primeiro, que se produciu como reacción fronte á reforma luterana, había que decidir se a lingua da Igrexa católica debía seguir sendo o latín ou, como postulaban os protestantes, debían pasar a ser as linguas vernáculas (Ferro Ruibal 1987: 28-29). A solución que se deu ao problema foi salomónica: mantívose o latín nos ritos litúrxicos, coma unha especie da lingua sacra, pero recurriuse ás linguas vernáculas na ensinanza e na evanxelización. O CVII foi crucial para a Igrexa católica, non só na dimensión lingüística. A súa apertura ao mundo moderno, o aggiornamento, significou o achegamento da distancia entre os crentes e Deus convertendo as súas relacións en máis directas e íntimas. De acordo con esta nova perspectiva, na comunicación entre o Pai e os seus fillos non se podía empregar o latín porque xa non era a lingua materna de ningún crente. Ao abandonar o latín neste tipo de comunicación, a Igrexa católica non decidiu recorrer ás linguas oficiais senón ás vernáculas. Esta conclusión conciliar tivo un peso inmenso precisamente no caso das linguas que non gozaban do estatus da oficialidade nos seus territorios. A actitude lingüística das igrexas locais despois do CVII puido decidir a sorte das linguas minorizadas fomentando o seu uso ou contribuíndo á súa extinción. Xoán XXIII na súa carta encíclica Pacem in Terris, dedicándolles ás minorías étnicas uns apartados no capítulo III, escribiu: «Deve-se declarar abertamente que é grave injustiça qualquer ação tendente a reprimir a energia vital de alguma minoria» (Xoán XXIII 1963). Porén, a elección da lingua vehicular da Igrexa non sempre respondía á realidade lingüística dos territorios da súa actuación. Tanto Galicia como Casubia son precisamente o tipo de minoría étnica que evoca Xoán XXIII (1963) na mencionada encíclica:

Caso peculiar desta situação é o processo político que se veio afirmando em todo o mundo, desde o século XIX, a saber, que pessoas de uma mesma raça aspirem a constituir- 
CAStro, O. / M. LiÑEIRA (eds.) (2015): Trama e urda. Contribucións multidisciplinares desde os estudos galegos, Santiago de Compostela, Consello da Cultura Galega. doi:10.17075/tucmeg.2015.

se em nação soberana. Entretanto, por diversas causas, nem sempre pode realizar-se este ideal. Assim dentro de uma nação vivem não raro minorias de raça diferente e daí surgem graves problemas.

Non son as únicas características que comparten estas dúas rexións, hainas moitas máis en tódalas dimensións: económicas, sociais, culturais, sociolingüísticas, xeográficas e históricas. Neste artigo, porén, limitarémonos a sinalar só as que teñen unha incidencia particular para a temática que tratamos. Ambas rexións están situadas no norte, na costa do mar, nunha localización periférica e, durante moito tempo no caso de Casubia, fronteiriza. Durante séculos a principal rama da economía destes territorios era a agricultura e a pesca. En Galicia, a debilidade das cidades galegas e, en Casubia, a concentración da aglomeración en Gdańsk provocou a predominancia do rural sobre o urbano. Aínda que o campesiñado dominaba cuantitativamente a sociedade galega e casubia, foron o clero e a fidalguía as clases que compartían o poder nestas rexións. A difícil situación económica destes territorios (baixo nivel de industrialización ata o século XX, dificultades para a labranza da terra, entre outros problemas) xerou a sangría migratoria aos países veciños e, desde a segunda metade do século XIX, tamén a América (no caso galego sobre todo a Arxentina, no casubio a Canadá e Brasil). Na orde política, o Reino de Galicia e os principados pomeranos de Casubia perderon a independencia na Idade Media pasando á dominación castelá e á alemá ou polaca, respectivamente. Tanto os galegos como os casubios pasaron pola traumática experiencia da guerra, a exterminación da súa intelectualidade e a implantación do réxime totalitario (franquismo en Galicia e comunismo en Polonia).

Unha atención especial merece o papel do párroco na sociedade campesiña e o lugar da parroquia rural na cultura galega e casubia. A autoridade exercida polo cura nas aldeas galegas e casubias era enorme ata non hai moito tempo e, en gran medida, mantense na actualidade. A parroquia aldeá desempeñou en boa parte da historia de Galicia o papel do centro cultural e social da vida labrega (Mandianes Castro 1997: 474). Xosé Chao Rego describe o adro da parroquia rural como «o lugar do encontro dominical no que «se fai parroquia)»), danse noticias e ás veces mesmo se realizan transaccións comerciais: un verdadeiro lugar de encontro, especie de «"praza maior»», que outras non existen» (Chao Rego 1988: 43-44). Na difícil historia de Casubia, dividida entre dúas potencias, pasando das man en man, a igrexa converteuse no factor identitario da nacionalidade casubia (no marco da nacionalidade polaca), o baluarte da súa tradición. Como escribía en 1967 Helena Przesławska, unha das primeiras sociólogas de Casubia: «a vida comunitaria da aldea casubia centrábase desde os comenzos da súa existencia, e segue centrándose ata hoxe, ao redor da igrexa e a parroquia como unha institución máis antiga e máis tradicional neste territorio. A parroquia en Casubia durante a longa dominación 
CAStro, O. / M. LiÑEIRA (eds.) (2015): Trama e urda. Contribucións multidisciplinares desde os estudos galegos, Santiago de Compostela, Consello da Cultura Galega. doi:10.17075/tucmeg.2015.

alemá foi un refuxio especialmente estable da poloniedade e centro da loita pola independencia» (Synak 1998: 110). ${ }^{81}$

A similitude de certas características e experiencias de Galicia e Casubia non significa en absoluto que non haxa diferenzas importantes entre elas. A diferenza fundamental, que hai que destacar ao principio, e a división do territorio primitivo de Casubia (Pomerania) entre Alemaña (Brandemburgo e Prusia) e Polonia na Idade Media. De todas formas, este territorio nunca chegou a formar un organismo estatal unificado compóndose de varios principados pomeranos. A unidade casubia máis forte foi o principado de Szczecin no que a elite local se xermanizou aínda antes da perda da independencia por considerar a cultura alemá máis atractiva. A parte de Casubia que permaneceu baixo a dominación alemá, foi sometida a un forte influxo do protestantismo. Foi precisamente a actividade do clero protestante nestes territorios coa que se relacionan os comenzos da tradición escrita en casubio no século XVI e XVII. Porén, á parte dalgúns textos de carácter relixioso desa época (Pontanus, Korfej), a lingua casubia tivo que agardar ata o século XIX para converterse nunha lingua literaria e escrita. Os avances na normalización do casubio, que se deron ao longo do século XX, víronse truncados pola Segunda Guerra Mundial e a implantación dun réxime totalitario en Polonia. Xunto á persecución da lingua levada a cabo polas autoridades comunistas, procedeuse á realización dunha política consistente na repoboación masiva e forzosa dos territorios casubios coa poboación doutras rexións polacas, por exemplo das terras do leste. ${ }^{82}$ A consecuencia deste proceso, a estrutura étnica de Casubia cambiou dramaticamente. O proceso da normalización lingüística, recobrado despois da democratización de Polonia (1989), aínda non alcanzou o nivel que ten actualmente o galego e os casubios non gozan dos dereitos dos que dispoñen os galegos no Estado español. A normativización do casubio, teoricamente rematada, dista moito de ser realmente aplicada na cultura e na sociedade (Synak 1998: 182). Aínda que no territorio central de Casubia entre un 80 e un $90 \%$ da poboación fala casubio (nas cidades e nos terreos fronteirizos esta porcentaxe descende ata o $10-15 \%$ ) e para o $60 \%$ é súa primeira lingua, a metade deles avergóñase da súa lingua e non a usa fóra do círculo familiar ou veciñal (Synak 1998: 182; Borzyszkowski/Mordawski/Treder 1999: 134).

\footnotetext{
${ }^{81}$ Todas as traducións do polaco son da autora.

${ }^{82}$ Aínda que esta medida foi motivada nun primer momento pola modificación das fronteiras despois da guerra, a elección do territorio non foi casual e non sempre as repoboacións coincidiron co fluxo migratorio; véxase, por exemplo, a moi controvertida acción Vístula no sueste de Polonia. Ademais, no caso dos territorios de Casubia e de Mazury o factor étnico foi moi confuso, xa que moitos dos seus habitantes, cidadáns polacos de antes da partición, ou tiñan unha identidade vacilante ou, aínda auntoidentificándose coa nacionalidade polaca, non foron percibidos como tales nin polas autoridades nin pola sociedade polacas. De todas formas e independentemente dos motivos desta medida, non se pode negar que a estrutura étnica e polo tanto a situación lingüística experimentaron en consecuencia cambios radicais (Borzyszkowski/Mordawski/Treder 1999: 64).
} 
CAStro, O. / M. LiÑEIRA (eds.) (2015): Trama e urda. Contribucións multidisciplinares desde os estudos galegos, Santiago de Compostela, Consello da Cultura Galega. doi:10.17075/tucmeg.2015.

A condición do casubio coma unha lingua codificada pero non normalizada así como a súa limitada área e o reducido número dos seus usuarios respecto ao galego non permiten facer unha comparación cuantitativa. ${ }^{83}$ Aínda se de todas formas quixeramos facer un estudo comparativo, para o caso de Casubia faltan datos básicos. Hai un certo número de investigadores que se dedican á problemática casubia desde as perspectivas sociolóxica, antropolóxica e histórica, entre outras. Porén estes estudosos non dispoñen do soporte económico suficiente para levar a cabo un proxecto estadístico que abranga todo o territorio de Casubia e se aplique con regularidade. En consecuencia, os datos que podemos adiantar na parte dedicada a Casubia son normalmente deficientes, imprecisos e os métodos de conseguilos non foron unificados.

O marco temporal elixido para o presente estudo é o período que transcorre desde o CVII (1962-1965) ata a actualidade. É evidente, porén, que para explicar certos fenómenos que están presentes ou xorden neste período, hai que retroceder ata as súas raíces en épocas anteriores. Por outra parte, as tendencias recentes que se observan nas Igrexas galega e casubia e a reestruturación da escena política en Casubia que se produce nos últimos anos impoñen unha extrema cautela no momento de sacar conclusións contundentes desta análise. ${ }^{84}$ Tamén cabe recordar que o período sinalado inclúe as épocas da explícita falta de liberdade de expresión tanto en Galicia (ata 1975) como en Casubia (ata 1989) que tivo unhas consecuencias determinadas para a situación lingüística dos territorios estudados.

Feitas as observacións previas, podemos agora indicar o obxectivo do estudo que é a busca dos factores que condicionan a actitude lingüística da Igrexa católica en Galicia e Casubia. Determinamos esta actitude a base de tres criterios principais: a presencia das linguas galega e casubia nas actividades da Igrexa (por exemplo, misas, celebracións, catequeses e publicacións); as declaracións respecto o idioma e o seu uso litúrxico por parte da xerarquía eclesiástica e do clero baixo; e, por último, a opinión sobre o papel da Igrexa no mantemento e a promoción da lingua vernácula expresada polos militantes do movemento nacional/rexional en Galicia e Casubia.

\footnotetext{
${ }^{83}$ Os datos dos que dispoñemos din que, no censo do 2011, das 229.000 persoas que declararon a nacionalidade casubia só 106.000 declararon o uso da lingua (GUS 2012: 118 e 120). En Galicia un 54,84\% dos 2.800.000 habitantes de Galicia declara un uso real do galego (Instituto Galego de Estatística). Debemos ter en conta que os datos non son comparables xa que no primeiro caso se fala do número das persoas que declaran a nacionalidade casubia, e no segundo dos habitantes de Galicia.

${ }^{84}$ A ruptura do monopolio da Asociación Casubia-Pomerana (Zrzeszenie Kaszubsko-Pomorskie / KaszëbskòPòmòrsczé Zrzeszenié) (ACP) e a aparición das tendencias máis esquerdistas e menos tradicionalistas no movemento nacional casubio.
} 
CAStro, O. / M. LiÑEIRA (eds.) (2015): Trama e urda. Contribucións multidisciplinares desde os estudos galegos, Santiago de Compostela, Consello da Cultura Galega. doi:10.17075/tucmeg.2015.

\section{A ACTITUDE LINGÜÍSTICA DA IGREXA CATÓLICA EN GALICIA}

O trazo máis característico do proceso da entrada do galego no ámbito relixioso é a iniciativa dos laicos. Foron as organizacións segrares (Deus Frantesque Gallaetiae e Mocedade Católica Galega, e máis tarde Boa Nova e Irimia) as que reclamaron o uso do galego na liturxia e propuxeron as primeiras traducións, non oficiais, do misal e da Biblia. Celebrado o CVII, as Igrexas locais tiveron que resolver por que linguas substituír o latín. De acordo coas directrices conciliares que falaban das linguas vernáculas e non oficiais, a Conferencia Episcopal Española (CEE) declarou que tales linguas en España eran catro: castelán, catalán, euskera e galego. Esta decisión da CEE abría ao galego as portas das igrexas galegas só en teoría, porque, segundo a Constitución «Sacrosanctum Concilium» (Art.36§3), a iniciativa perténcelle á autoridade eclesiástica local. No boletín do Arcebispado compostelán do 20 de decembro de 1964 lemos que a lingua vernácula de Galicia é o castelán e desde xaneiro do ano seguinte introduciuse o misal neste idioma en tódalas igrexas galegas (López Muñoz 1989: 33). Ao mesmo tempo, na prensa local galega, desenvolvíase o debate sobre o uso do galego na liturxia. O punto culminante da discusión foi a publicación da carta aberta aos bispos de Galicia, en prol da introdución do galego na Igrexa, firmada por 1.200 persoas, moitas delas representantes da vida cultural. O emprego litúrxico do galego foi finalmente autorizado en 1969, pero o primeiro misal oficial nesta lingua non foi publicado ata 1988 e a Biblia ata dous anos despois. Aquelas publicacións ían eliminar os últimos obstáculos nunha plena entrada do galego nas igrexas, pero a situación non cambiou substancialmente. Dez anos despois, as misas galegas tiñan lugar só nun $14 \%$ das parroquias constituíndo un $7 \%$ do total das misas dominicais (López Muñoz 1989: 201). Aínda que estes datos non deixan supoñer un cambio radical na actitude lingüística da Igrexa en Galicia nos próximos anos, cabe apuntar a aparición dun fenómeno recente no clero baixo galego. No ano 2009 formouse o Foro de Curas Galegos Bispo Araúxo que no seu manifesto asegurou que «hai unha Igrexa galega que existe e resiste» (Galicia Dixital).

Victorino Pérez Prieto, cura que dedicou varios libros ao tema do galeguismo e a relixión, recoñecendo o papel dalgúns clérigos para a cultura galega, di: «a realidade é que os galeguistas desconfían da Igrexa porque a Igrexa desconfía dos galeguistas» (Pérez Prieto 1996). Efectivamente, nas conversacións privadas cos galeguistas que a autora tivo ao longo dos últimos seis anos da recolleita do material para este artigo, non atopou nin unha soa persoa que defendera decididamente a postura da Igrexa católica fronte á cultura propia de Galicia. Si houbo algunhas que a matizaron como Xesús Ferro Ruibal (Santiago de Compostela, 2007) e Benito González Raposo (Santiago de Compostela, 2007). Porén, a opinión da inmensa maioría dos meus interlocutores foi 
CAStro, O. / M. LiÑEIRA (eds.) (2015): Trama e urda. Contribucións multidisciplinares desde os estudos galegos, Santiago de Compostela, Consello da Cultura Galega. doi:10.17075/tucmeg.2015.

negativa neste sentido considerando a Igrexa como un dos grandes factores da castelanización de Galicia, como mo expresaron por exemplo Manuel González González (Varsovia, 2008) e Xosé Enrique Costas (Allariz, 2007).

De forma que a pregunta feita publicamente en 1960 por Otero Pedrayo a Ángel Temiño Saiz (bispo de Ourense entre 1952 e 1987): «¿Por qué a Igrexa non reza en galego?» (López Muñoz 1989: 31) parece seguir vixente no ano 2013. Aínda que Pedrayo non recibiu a resposta á súa pregunta, o bispo Temiño dixo noutra ocasión: «El pueblo gallego no entiende el gallego» (López Muñoz 1989: 46). Foi da mesma opinión Vicente Enrique y Tarancón (primado de España nos anos 1969-1971, presidente da CEE entre 1971-1981) quen afirmou en 1968: «En Galicia no se habla gallego» (López Muñoz 1989: 41). Porén foi José Guerra Campos (de orixe galega, bispo auxiliar de Madrid-Alcalá desde 1964, Secretario Xeral da CEE) quen máis atinadamente resumiu a actitude lingüística do clero galego: «Yo no me presentaría ante Dios en alpargatas» (López Muñoz 1989: 34). Por outra banda, non debemos esquecer os exemplos, por moi poucos que sexan, dunha postura máis favorable coa lingua galega, como a de Manuel Lago González (bispo de Tui nos anos 1917-1923, arcebispo de Santiago de Compostela entre 1923 e 1925) e Fernando Quiroga Palacios (bispo de Mondoñedo desde 1945, arcebispo de Santiago de Compostela desde 1949). No primeiro caso, trátase de anos moi anteriores á celebración do CVII, cando, de acordo coas directrices do Concilio de Trento, as linguas vernáculas podían aplicarse só na actividade catequética. En todo caso, este bispo empregaba o galego máis ben na súa actividade artística. O segundo foi unha figura controvertida, pero non se lle poden negar os méritos no campo da liturxia galega xa que foi o primeiro cardeal que celebrou misa nesta lingua. Porén, o exemplo máis pertinente dun maior compromiso coa lingua galega é o patrón do xa mencionado Foro de Curas Galegos. O bispo Araúxo escribiu na súa Memoria da vida (1993): "A Igrexa galega ten unha débeda e un pecado histórico con respecto ó noso pobo: esquecer a nosa lingua e a nosa cultura» e «Ser galego e non exercer de galego é unha esquizofrenia mental e cordial. E aínda máis, para un cristián é un pecado contra o misterio da encarnación» (Galicia Dixital).

Hai máis de vinte anos os párrocos en Galicia declarábanse na súa maioría proclives ao uso do galego en liturxia (en varias proporcións co castelán), pero despois de dez anos seguían sen empregalo o que levou a Daniel López Muñoz a realizar outro estudo sociolóxico para entender as causas desta actitude (López Muñoz/García Cendián 2000: 9). Na Carta da parroquia de Santa Eulalia de Vedra o párroco Armindo Iglesias, preguntado por que non a fai en galego, contesta: «También mis padres usaron el arado romano y el carro de bueyes y ahora se usa el tractor, el coche y máquinas modernas. 
CAStro, O. / M. LiÑEIRA (eds.) (2015): Trama e urda. Contribucións multidisciplinares desde os estudos galegos, Santiago de Compostela, Consello da Cultura Galega. doi:10.17075/tucmeg.2015.

[...] Cada año dicen que desaparecen del mundo unos 50 idiomas. Lástima que no desaparezcan muchos más» (Iglesias 2008: 9).

No século XIX a Igrexa optou polos fillos dos campesiños nos seminarios para asegurarse o apoio desta clase social na súa loita co liberalismo (Mariño Paz 1998: 340). Como os labregos en Galicia eran daquela practicamente monolingües en galego, a lingua da instalación do clero tivo que ser tamén o galego (Mariño Paz 1995: 563n). Aínda hoxe a primeira lingua dun $73 \%-75 \%$ dos párrocos en Galicia é o galego (Ferro Ruibal 1990: 351; López Muñoz/García Cendián 2000: 9) polo cal resulta evidente que o lugar da formación dos futuros cregos tivo que ser un factor decisivo na súa actitude lingüística. $O$ xa mencionado párroco de Santa Eulalia de Vedra lembra nas páxinas da Carta da parroquia: «Por los años 1940 nos prohibían hablar Gallego en el Seminario» (Iglesias 2008: 10). Un dos poucos que combatían os castigos por falar galego nos seminarios foi Manuel Espiña Gamallo (director espiritual do Seminario Menor de Belvís en Santiago de Compostela), pero non puido evitar a estigmatización dos galego-falantes polos compañeiros (Gómez González 2010; Ferro Ruibal 2000: 43). O galego, xa asociado socialmente coa rusticidade, quedaba así relegado ao uso íntimo marcado polo sentimento de inferioridade e o castelán adquiría os trazos da universalidade no emprego diario e da sacralidade no litúrxico. Ferro Ruibal, seminarista nos anos sesenta, testemuña:

Eu mesmo, se o cardeal Quiroga non me mandase a estudiar a Roma, posiblemente non descubriría a miña galeguidade. [...] No Seminario viviamos un falso universalismo que nos facía pensar que nós estabamos fóra do mapa, cando era precisamente porque estabamos neste punto concreto do mapa polo que viviamos esta estúpida situación. Foi grande a miña sorpresa ver de repente que nin ós cataláns, nin ós vascos nin a moitos compañeiros de razas distintas que alá tiven lles pasaba semellante cousa. Este falso universalismo tíñanos en Babia, nin eramos deste tempo e desta terra nin eramos capaces de sintonizar coas directrices da Igrexa universal. (Ferro Ruibal 1990: 48)

$\mathrm{Na}$ actualidade, a lingua galega non está perseguida nos seminarios e os seminaristas decláranse libres dos prexuízos lingüísticos valorando positivamente a introdución deste idioma na liturxia (López Muñoz 1989: 149n).

Sexan libres destes prexuízos ou non, os cregos galegos son conscientes da súa existencia xa que maduraban nunha Galicia marcada polo autoodio. O sentimento de inferioridade dos galegos vén de antano e asentouse socialmente ao longo dos séculos. Desde a Idade Media, cando o Reino de Galicia empezou a facer parte da Coroa de Castela e León, a elite autóctona foi paulatinamente substituída pola foránea. A política centralizadora dos Reis Católicos e posteriormente dos Borbóns impuxo o castelán como o idioma oficial do 
CAStro, O. / M. LiÑEIRA (eds.) (2015): Trama e urda. Contribucións multidisciplinares desde os estudos galegos, Santiago de Compostela, Consello da Cultura Galega. doi:10.17075/tucmeg.2015.

Estado. A dependencia económica de Madrid e a condición periférica da rexión impediron o debido desenvolvemento da industria, do comercio e, moi especialmente, da agricultura. A conseguinte perda do equilibrio poboaciónrecursos fixo de Galicia a principal provedora de man de obra barata noutras partes da Península Ibérica. Emigraban, loxicamente, os máis desfavorecidos que pertenecían ás camadas baixas da sociedade galega. O contacto cos inmigrantes era moitas veces a única experiencia galega que tiñan os habitantes das rexións de acollida. Non obstante, este contacto limitado e unilateral foi suficiente para que se formara o estereotipo negativo do galego en España e Portugal. Proba diso é a imaxe dos galegos que xorde do teatro do Século de Ouro español e da literatura de cordel portuguesa. O mesmo galego estereotipado aparece no villancico de gallego (vs. villancico en gallego; Villanueva 1994: 78) tan popular nas catedrais castelás, andaluzas e portuguesas hasta finais do século XVIII. Aínda peor presentada está Galicia e as súas xentes na Descripción del Reyno de Galicia (atribuído erroneamente a Góngora; Filgueira Valverde 1969: 239), Cierto castellano empleado en Galicia hace la descripción siguiente del Reyno y sus gentes e outros versos inxuriosos do XVIII. A persistencia deste estereotipo negativo do galego obsérvase nos chistes que se contan actualmente sobre os galegos en Latinoamérica:

Un gallego le dice a otro:

Oye, Manolo, pásame otro shampoo.

Pero si ahí en el baño hay uno.

Sí, hombre, pero este es para cabello seco y yo ya me lo he mojado.

Ou este outro:

¿Por qué un gallego mira fijamente el cartón de jugo?

Porque tiene escrito «concentrado».

Do predominio da agricultura na economía galega souberon beneficiarse dúas clases sociais: o clero e a fidalguía. A burguesía galega, pouca e débil, quixo aproveitar o nacente liberalismo para disputar o poder destas dúas camadas sociais. Recorrendo á súa ferramenta habitual, a prensa, os liberais galegos trataron de captar $o$ apoio do campesiñado por medio dos escritos propagandísticos en lingua galega que apareceron durante a primeira metade do século XIX (o prerrexurdimento). A recuperación do uso culto desta lingua realizouse só na segunda metade do século XIX grazas á actividade dos galeguistas. A pesar dos avances da desamortización, daquela a Igrexa católica aínda era unha institución potente en Galicia, porque aínda perdendo o poder económico (os dezmos, as rendas feudais, o voto de Santiago), mantivo o social e o político. Os poetas civís como Rosalía de Castro e Manuel Curros Enríquez, cuxo obxectivo non foi soamente mellorar a condición da cultura galega senón protestar pola dramática situación dos labregos e doutros colectivos marxinais, non podían menos que chocar coa 
CAstro, O. / M. LiÑEIRA (eds.) (2015): Trama e urda. Contribucións multidisciplinares desde os estudos galegos, Santiago de Compostela, Consello da Cultura Galega. doi:10.17075/tucmeg.2015.

Igrexa. Ambos tiveron enfrontamentos máis ou menos frontais co clericalismo. A imprenta que ía imprimir un artigo de Castro foi apedrada polos seminaristas. Curros Enríquez foi denunciado polo bispo de Ourense, Cesáreo Rodrigo, e procesado pola publicación do seu primeiro tomo de poesías en galego, Aires da miña terra (1880). No poema que máis atención chamou durante o proceso, «Mirando ó chau», Curros concretou axeitadamente a orixe da discrepancia entre a Igrexa e o galeguismo: «Si eu fixen tal mundo, / que o demo me leve» (Curros Enríquez 1990: 161). O parentesco entre o galeguismo, tanto cultural como político, no século XIX co liberalismo e despois coa esquerda é unha constante na historia deste movemento. A primeira formación que representaba os intereses de Galicia na escena política, o Partido Galeguista, pese á presencia dalgúns militantes de dereitas, decidiu formar parte do Frente Popular en 1936. Os grupos aparecidos durante o franquismo, como Brais Pinto, as formacións como Partido Socialista Galego e a Unión do Pobo Galego confirman a alianza do movemento nacional galego coa esquerda. Finalmente, na actual escena política galega están presentes os partidos galeguistas de esquerdas, como o Bloque Nacionalista Galego e a Frente Popular Galega, pero falta a dereita nacionalista. De xeito que, aínda se podemos destacar certos políticos galeguistas doutras opcións, queda patente a ausencia dunha tradición nacionalista de dereitas en Galicia.

\section{A ACTITUDE LINGÜÍSTICA DA IGREXA CATÓLICA EN CASUBIA}

A lingua de Casubia entrou no ámbito relixioso paralelamente a súa estrea na literatura e da man da maior expoñente do rexurdimento cultural casubio. Florian Ceynowa traduciu ao casubio os dez mandamentos, o Pai Noso e compuxo algunhas oracións orixinais ao redor do ano 1850. Ao cabo de case un século, en 1935, outros dous poetas famosos pertenecentes ao grupo Zrzeszeńcy, Jan Trepczyk e Aleksander Labuda, publicaron unha serie de cancións relixiosas das cales a máis acabada artisticamente é o Pai Noso. Xa na época comunista, nos anos sesenta, o casubio adoitaba aparecer nalgunhas celebracións relixiosas, como a coroación de Swiónowsczi Matinczi en 1966. A súa introdución non oficial na liturxia dominical arrancou a partir dos anos oitenta, cando o casubio xa estaba presente na actividade extralitúrxica da Igrexa, como a catequese (Synak 1998: 218; Labuda 2007). Nos anos noventa rematou o traballo tradutor de Franciszek Grucza (Evanxelio, 1992) e Eugeniusz Gołąbek (Novo Testamento, 1993) así como a elaboración dos demais soportes textuais necesarios para a autorización do uso do casubio na liturxia. En 1993, a Arquidiócese de Gdańsk autorizou as misas casubias acompañando esta decisión coas «Instrucións sobre a presencia da lingua 
CAStro, O. / M. LiÑEIRA (eds.) (2015): Trama e urda. Contribucións multidisciplinares desde os estudos galegos, Santiago de Compostela, Consello da Cultura Galega. doi:10.17075/tucmeg.2015.

casubia na liturxia e na vida da Arquidiócese de Gdańsk» (Wskazania duszpasterskie $w$ sprawie obecności języka kaszubskiego $w$ liturgii $i$ życiu Archidiecezji Gdańskiej, 23.05.1993). Segundo lemos neste documento, aos párrocos non só se lles permite misar en casubio, senón que se lles alenta ao seu uso litúrxico e insístise na necesidade de fomentar e protexer calquera iniciativa dos fregueses neste sentido (Archidiecezja Gdańska). Nos anos noventa tamén se publica un libro de oracións que, na súa segunda edición, vai acompañado cunha dedicatoria de Xoán Pablo II escrita en casubio. En 2005, formouse a Comisión de Asuntos Eclesiásticos da ACP. Na comisión eclesiástica (como a chamaban os seus membros) reuníanse os representantes do movemento nacional casubio (ACP) e os da Igrexa católica para planear e organizar unha plena entrada do casubio no ámbito relixioso. O froito da súa actividade foi unha intensa labor editorial e o seu grande mérito foi a formación lingüística do clero que servía nas parroquias de Casubia. En 2010 a comisión foi clausurada por varias razóns. Por unha banda, cumpríranse a maioría dos obxectivos que inspiraran a súa fundación. Por outra banda, á cúpula da ACP chegou unha nova xeración de militanes que non consideraban a relixión coma o ámbito máis importante da súa actividade (Pryczkowski sen data b). ${ }^{85}$

É difícil estimar o número das misas casubias celebradas na actualidade por unha ausencia completa de datos. Segundo o parecer do presidente da clausurada comisión eclesiástica, Eugeniusz Pryczkowski, o seu número seguramente descendeu nos últimos anos. Moitas desas misas foran fomentadas polos militantes da ACP cuxa iniciativa era especialmente importante nas grandes cidades (Gdańsk, Gdynia, Sopot) onde o nivel do uso do casubio é moi baixo. As misas no interior de Casubia, nas aldeas e nas cidades pequenas, dicíanse en casubio maioritariamente pola iniciativa dos mesmos párrocos e estas normalmente mantéñense (Pryczkowski sen data a).

$\mathrm{Na}$ recepción do premio polos méritos para a provincia pomerana o 25 de xaneiro de 2010 en Gdańsk, Jan Bernard Szlaga (bispo de Pelplin nos anos 1992-2012) dixo que esta distinción aledábao especialmente xa que era a expresión da gratitude da súa «Patria pequena» (Szmagliński 2010). Polo que din os políticos, escritores e investigadores casubios, o seu país efectivamente está en débeda coa Igrexa católica. Na entrevista «Jak Kaszuba z Kaszubą» feita por Tomasz Żuroch-Piechowski, o profesor Gerard Labuda (o historiador de Casubia máis coñecido e estimado) insiste varias veces no papel da Igrexa católica na preservación da identidade e lingua casubia (Labuda 2007). Brunon Synak (investigador, presidente da ACP entre 1998-2004), no seu comentario ao último censo da poboación en Polonia (2011), falando nunhas palabras pouco optimistas sobre as perspectivas da fala casubia mencionou a Igrexa, xunto coa

\footnotetext{
${ }^{85}$ Agradézolle a Eugeniusz Pryczkowski que puxese ao meu dispor varios manuscritos da súa autoría.
} 
CAStro, O. / M. LiÑEIRA (eds.) (2015): Trama e urda. Contribucións multidisciplinares desde os estudos galegos, Santiago de Compostela, Consello da Cultura Galega. doi:10.17075/tucmeg.2015.

escola e os medios de comunicación, como unha institución que axuda a manter a lingua que está en vías de extinción (Synak 2011).

Aínda que os intelectuais de Casubia evolucionaron ata a postulación da introdución do casubio na Igrexa (o memorial da intelectualidade casubia atopado durante a revisión do piso de Aleksander Labuda en 1960), os primeiros rexionalistas casubios máis ben defendían o emprego do polaco neste ámbito. Un dos principais militantes casubios, Aleksander Majkowski, estaba convencido de que «a lingua da Igrexa debe ser, como o foi desde hai séculos, a lingua literaria polaca» (cit. en: Borzyszkowski et al. 1999: 136). Non tiñan estes reparos os xerarcas da Igrexa, ata os seus máximos expoñentes. Xoán Pablo II, durante dúas visitas a Casubia, evocou nos seus discursos o alto valor da cultura casubia. En 1987, en Gdynia, o Papa dirixiuse ao seu público: «Queridos irmáns e irmás casubios, protexan estes valores e esta herdanza que constiúe a vosa identidade» (Archidiecezja Gdańska). En 1999, repetiu o seu chamamento: «Saúdo ao pobo casubio, os anfitrións seculares desta terra pomerana. Faleivos en Gdynia en xuño de 1987. Desexo alentarvos outra vez a protexer a vosa identidade coidando as relacións familiares, perfeccionando a vosa lingua e transmitindo a vosa rica tradición á nova xeración. Estade con Deus sempre!» (Archidiecezja Gdańska). Para moitas persoas, estas palabras foron decisivas para a formación da súa actitude lingüística na actividade pastoral como o testemuña o cura de orixe casubia, Grzegorz Ruchniewicz, na carta dirixida á comisión eclesiástica da ACP (Pryczkowski sen data b). Na introdución ao cancioneiro Dlô Was Panie (2006), o arcebispo de Gdańsk (1984-2008), Tadeusz Gocłowski, escribiu: «A riqueza da nosa cultura é un valor que hai que protexer. A cultura casubia enfróntase con moitas dificultades. En varios momentos da súa historia tivo que loitar pola supervivencia. Agora a maior dificultade está na asociación da cultura casubia cun folclore, cunha tradición rural, coa vida privada. Hai que combatelo» (Pryczkowski sen data c). Outro xerarca, de orixe casubia, Henryk Muszyński (arcebispo de Gniezno entre 1992 e 2010, primado de Polonia nos anos 2009-2010), dixo:

Os fragmentos da liturxia na lingua casubia deben ser presentes en toda Casubia. Creo que é importante por dúas razóns. A primeira razón é a nosa integración con Europa, integración non significa unificación. Hai que coidar as diferenzas. Como temos unha tradición tan fermosa como é a nosa lingua casubia, deberiamos coidala moi conscientemente. A segunda razón é a globalización que pode ser moi perigosa se se a trata dunha maneira superficial. A referencia ás raíces e á lingua dos antepasados favorece unha reflexión profunda sobre a propia formación espiritual. (Perszon 2005)

Aos representantes da xerarquía, segue unha longa listaxe dos cregos comprometidos coa cultura casubia que empeza na segunda metade do século XIX. Ignacy Cyra (o primeiro presidente da asociación Casubia Nova), Leon 
CAstro, O. / M. LiÑEIRA (eds.) (2015): Trama e urda. Contribucións multidisciplinares desde os estudos galegos, Santiago de Compostela, Consello da Cultura Galega. doi:10.17075/tucmeg.2015.

Heyke (militante de Casubia Nova), Bernard Sychta (etnógrafo de Casubia), Franciszek Grucza (vinculado a Zrzesz Kaszëbskô), Antoni Pepliński (poeta e compositor) son só algúns exemplos da actividade cultural e política do clero a favor da súa patria pequena. O cura Grzegorz Ruchniewicz na mencionada carta á comisión eclesiástica da $\mathrm{ACP}$ escribiu: «O casubio non pode ser só asunto dos casubios: vivimos no mesmo país e o casubio debe ser percibido como o tesouro de todos!» (Pryczkowski sen data b).

Unha actitude tan unívoca do clero fronte ao idioma casubio tivo que ser formada en parte polo menos polos profesores e polo ambiente xeral dos seminarios en Casubia. O seminario máis importante neste sentido é o Seminario de Pelplin que organiza desde 1980 os Encontros de Pelplin aos que invita investigadores e, no período democrático tamén representantes das autoridades locais, para discutir sobre o presente e futuro de Casubia. Neste mesmo seminario funciona ata hoxe o Círculo dos Estudantes Casubios (Koło Studentów Kaszubów/Klub Sztudérów Kaszëbów) fundado en 1908 por Jan Karnowski, ideólogo e militante de Casubia Nova. Os estudantes escriben na súa páxina web: "A súa actual función [do Círculo] é a continuación das tradicións casubias e o cultivo da identidade rexional casubia» (Koło Studentów...). O círculo publica a revista Zwónk Kaszëbsczi redactada integramente en casubio (Obracht-Prondzyński 2007: 42) e co apoio do bispo de Pelplin, Jan Bernard Szlaga, falecido recentemente (Kośierzyna, nasze miasto 2005). Os seminaristas agrupados no círculo participan tamén activamente na promoción da cultura e lingua casubia (Kośierzyna, nasze miasto 2005). No seminario de Pelplin, os estudantes poden ademais redactar as emisións de radio Gtos en casubio, escoitar as misas en casubio, dicir oracións en casubio e asistir aos cursos deste idioma. Os círculos casubios existían tamén noutros seminarios de Casubia, como o lembra Bogusław Głodowski (un dos primeiros en misar en casubio) quen estudou no Seminario de Gdańsk-Oliwa nos anos 1977-1983:

Os profesores tiñan unha actitude favorable á cultura da patria pequena. [...] Tivemos algúns encontros no marco do círculo de seminaristas casubios, por exemplo con Profesor Jerzy Samp, Wojciech Kiedrowski, Edmund Puzdrowski. No xornal do seminario Novellae Olivarum publicábanse os artigos escritos por seminaristas casubios sobre Casubia, a súa historia, tradición e cultura. Durante a miña carreira coñecín tamén ao párroco de Sopot, o «Rei Casubio», do seminario de Chełm, Franciszek Grucza. (Głodowski 2006)

Tamén hoxe funciona neste seminario o Círculo Casubio (Koło Kaszubskie), reactivado no ano 2010, sobre o que escriben os seus responsables: «O obxectivo do grupo é sobre todo o mantemento das tradicións casubias e, tamén, o coñecemento e perfeccionamento da lingua. Con este fin os membros do 
CAStro, O. / M. LiÑEIRA (eds.) (2015): Trama e urda. Contribucións multidisciplinares desde os estudos galegos, Santiago de Compostela, Consello da Cultura Galega. doi:10.17075/tucmeg.2015.

grupo organizan numerosas representacións así como asisten ás misas na lingua casubia» (Gdańskie Seminarium Duchowne).

Ao contrario do que podería parecer, a lingua casubia nin goza na actualidade nin gozaba na súa historia dun prestixio similar, nin sequera entre o clero. A consecuencia da xermanización das clases altas e medias casubias entre os séculos XII-XV na parte alemá e, despois da primeira partición de Polonia (1772), tamén nos territorios anteriormente polacos, a lingua e a cultura casubia foron conservadas polas camadas baixas. Sobre os casubios, a súa lingua e cultura, pesaban os mesmos prexuízos que sobre os galegos. Gottlieb Leberecht Lorek, un pastor alemán que traballou na terra casubia na primeira metade do século XIX, escribe que os casubios son de carácter escravo, cobizosos, proclives ao roubo e á malicia: «O descoido no fogar e a roupa lixada están difundidas entre os casubios nun grao máximo» (Lorek 2009: 61). En canto á lingua, Lorek afirma que soa dun xeito «repugnante» (Lorek 2009: 60). O clero casubio tampouco foi impermeable a estes prexuízos. Aleksander Hilferding, investigador ruso que visitou Casubia na metade do século XIX, describía así a actitude da fidalguía e o clero polaco respecto á cultura e á lingua casubias:

Polonia, que durante tantos séculos reinaba en Pomerania, podía doadamente construír a irmandade con el [o pobo casubio]. Non o fixo polo eterno desprezo que sentía cara ao pobo baixo. Os casubios son uns campesiños primitivos, a súa lingua é o dialecto feo do polaco; como os grandes señores ían a ocuparse do pobo baixo e a súa lingua primitiva? Esta é a opinión dos polacos-herdeiros que conservaron aínda parte das súas terras en Casubia. Na conversación comigo chegaban a rir de que me interesasen os casubios e a súa lingua. [...] O clero católico neste país [...] oponse á xermanización. Porén, desgraciadamente, a maioría dos seus representantes sente o mesmo orgullo aristocrático ante os casubios e o seu dialecto. (Hilferding 1989: 21)

Como a Igrexa protestante foi un dos axentes da xermanización nas terras de Casubia, xurdiu a asociación do alemán co protestantismo e do polaco co catolicismo (Synak 1998: 12-13). Os casubios que se converteron ao protestantismo foron rexeitados pola comunidade como outros e o seu nome (Pomereniek) foi a maior ofensa para os casubios católicos. Deste xeito a relixión converteuse nun referente de identidade máis importante cá lingua (o Pomereniek conservou a súa lingua). (Synak 1998: 107 e 177) A xermanización da elite privou a Casubia da súa clase dirixente. A clase media casubia formouse a base dos campesiños-propietarios que se beneficiaron da reforma agraria levada a cabo polo Estado prusiano. A nova intelectualidade casubia (médicos, avogados, mestres, entre outras profesións) recolleu a idea do rexurdimento nacional dentro do grande movemento étnico eslavo. Conscientes da súa debilidade, os dirixentes casubios decidiron integrarse no movemento nacional polaco, o que non foi unha decisión doada. Os recordos que tiñan os casubios da 
CAstro, O. / M. LiÑEIRA (eds.) (2015): Trama e urda. Contribucións multidisciplinares desde os estudos galegos, Santiago de Compostela, Consello da Cultura Galega. doi:10.17075/tucmeg.2015.

dominación polaca nos seus territorios non eran precisamente os mellores, como escribía Jan Karnowski en 1911: «O pobo casubio durante moito tempo, porque ata a metade do século pasado non era polaco non tiña a poloniedade na alma. $\mathrm{O}$ que conservou do pasado da Polonia antiga foi a relixión católica e a lingua polaca na igrexa. Á parte diso sabe só que existiu a Polonia grande, a Polonia fidalga, a Polonia inxusta» (Obracht-Prondzyński 2003: 175). Mentres tanto, os polacos comprometidos coa loita pola independencia de Polonia desconfiaban dos casubios acusándoos de afiliación alemá.

En 1912 os representantes do movemento cultural e nacional casubio fundaron en Gdańsk a súa primeira asociación, Casubia Nova (Towarzystwo Młodokaszubów / Towarzëstwò Młodokaszëbów), que tiña como obxectivo despertar a identidade propia do pobo casubio dentro da nacionalidade polaca. Aleksander Majkowski, o secretario e o líder informal de Casubia Nova, dicía: «O que é casubio, é polaco» (Synak 1998: 156). Aínda que os casubios loitaron pola independencia de Polonia, sentiron a instauración da Segunda República Polaca como un grande desencanto, porque o territorio de Casubia foi dividido en tres partes entre Polonia, Alemaña e a Cidade Libre Gdańsk (Danzig). Ademais, os casubios eran tratados como cidadáns de segunda clase, por exemplo, foron apartados da administración en Casubia e nas cidades non se empregaba aos obreiros de orixe casubia. A pesar diso, os escritores e políticos casubios reunidos en torno á revista Zrzesz Kaszëbskô (o grupo chamado Zrzeszeńcy) intentaron loitar polo mantemento da lingua, diferenciación cultural e identidade casubia no marco da nacionalidade polaca polas súas ideas radicalmente antialemás.

Cando Alemaña invadiu Polonia iniciando a Segunda Guerra Mundial, os casubios maioritariamente loitaron na súa defensa. Trala capitulación da Segunda República Polaca, o exército alemán executou a maior parte da intelectualidade casubia, mentres que aos outros habitantes de Casubia se lles obrigaba a alistarse a Wermaht e inscribíanse nas listas alemás. Despois da guerra, instalouse a República Popular de Polonia que na propaganda comunista era un Estado «homoxéneo nacionalmente». Os casubios, sospeitosos de ser os aliados dos alemáns, eran abertamente perseguidos polas autoridades polacas. Por exemplo, no exército eran relegados ás campañas mineiras que quedaban lonxe da súa terra natal; ás escolas en Casubia traíase aos profesores doutras partes de Polonia; os casubios non tiñan acceso á administración local; e durante algúns anos impúñaselles ás universidades rexeitar aos estudantes-candidatos de orixe casubia. O grao de aversión das autoridades cara a Casubia era tal que nunha das instrucións internas do Partido Obreiro Unificado Polaco (Polska Zjednoczona Partia Robotnicza) recomendábase evitar a palabra «casubio» substituíndoa por expresións descritivas como «a poboación local» (Synak 
CAStro, O. / M. LiÑEIRA (eds.) (2015): Trama e urda. Contribucións multidisciplinares desde os estudos galegos, Santiago de Compostela, Consello da Cultura Galega. doi:10.17075/tucmeg.2015.

1998: 140). Danuta Stenka (actriz de orixe casubia) lembra así a súa nenez en Gowidlino (Gòwidlëno), unha aldea en Casubia:

Sei que a xeración dos meus pais foi perseguida pola súa identidade diferente. Primeiro polos alemáns e despois, xa trala guerra, traían os profesores de outras partes do país para erradicar todo tipo de rexionalismo. O meu pai contoume que tiña unha profesora traída do leste que lles pegaba por falar casubio. Supoño que os meus pais querían aforrarnos iso. De todas maneiras, aínda que eu entendía casubio, non o usaba. (Stenka 2012: 85)

Parece que o estereotipo negativo do casubio xa non se matén tanto na actualidade, pero non hai moito tempo repetíanse en Polonia proverbios tales como «Arenque non peixe, casubio non home», «O bo casubio é o casubio morto», «A machada é para afiar, o casubio para embotar» e «Vende o cabalo, merca o casubio: come pouco, traballa moito» (Synak 1998: 125).

$\mathrm{Na}$ época comunista, a pesar de todo, os casubios declarábanse polacos (a dobre identidade: rexional casubia e nacional polaca), pero a súa actitude fronte ao Estado polaco mudou. Lech Bądkowski, o principal ideólogo casubio deste período, explicaba que, como Casubia foi deixada soa na súa historia, debería funcionar en Polonia coma unha patria pequena pola que coida a súa nación pequena (Synak 1998: 157). Esta idea dos casubios-anfitrións das súas terras foi sentenciada por Aleksander Labuda nestas palabras que expresan perfectamente a ambigüidade do sentimento nacional casubio: «A Casubia o que é casubio, a Polonia o que é polaco» (Synak 1998: 158). A expresión desta nova filosofía foi a fundación da Asociación Casubia en 1956 (ACP desde 1964) que se converteu nunha ferramenta política moi eficaz. O papel simbólico de Lech Wałęsa e da cidade de Gdańsk déronlle un protagonismo especial a Casubia na transición democrática polaca. A clase dirixente formada no seno da ACP soubo aproveitar os cambios democráticos chegando aos cargos máis elevados da administración non só local senón tamén estatal (Borzyszkowski / Mordawski / Treder 1999: 70).

\section{CONCLUSIÓNS}

A actitude lingüística da Igrexa en Galicia e Casubia é diferente. Non tanto pola cantidade das misas na lingua vernácula, que, aínda que é difícil de estimar no caso casubio, pode non diferir tanto ou ser incluso menor, senón polo significado simbólico desta presenza. Tratándose da cultura dunha antiga tradición literaria e dunha innegable riqueza, dunha lingua normativizada, cooficial e cun grande número de usuarios, a súa presenza nas igrexas galegas resulta anecdótica. Os exemplos ilustres dos eclesiásticos que empregaron e defenderon o galego na actividade pastoral non poden ocultar as declaracións contrarias, expresadas moitas veces dun xeito pouco 
CAStro, O. / M. LiÑEIRA (eds.) (2015): Trama e urda. Contribucións multidisciplinares desde os estudos galegos, Santiago de Compostela, Consello da Cultura Galega. doi:10.17075/tucmeg.2015.

contrarias, expresadas moitas veces dun xeito pouco diplomático, acerca do uso litúrxico desta lingua dos principais representantes da Igrexa. Pola outra banda temos un grupo étnico dunha identidade nacional vacilante, unha cultura cuxa literatura non se remonta máis de dous séculos, e unha lingua que non empezou ben o proceso da normalización e xa está en vías de extinción. Porén, a Igrexa en Casubia non vacilou en apostar por esta cultura e esta lingua tratando o asunto con extrema delicadeza.

Buscando o factor determinante na elección da lingua de comunicación da Igrexa católica en Galicia e Casubia, repasamos as posibles causas dunha actitude eclesiástica favorable ou reticente cara ás linguas vernáculas nestas rexións. Tanto Galicia como Casubia foron subordinadas a entidades estatais máis fortes e non conseguiron recuperar a independencia. En ambas rexións produciuse o relevo aristocrático e o influxo cultural e lingüístico foráneo. Como consecuencia destes procesos, a cultura galega e casubia foron asociadas coa ruralidade e as linguas foron relegadas unicamente ao uso privado das clases sociais baixas. As dificultades económicas en ambas rexións impuxeron aos labregos galegos e casubios a emigración a terras veciñas ou a América en busca do sustento. O rexurdimento cultural e nacional que xurdiu na segunda metade do século XIX non atopou unha base ampla nin en Galicia nin en Casubia. Ata ese momento, nin en Galicia nin en Casubia o clero se vira atraído pola cultura e lingua galega e casubia desprezándoas igualmente nos dous casos. Parece que as primeiras formulacións rexionalistas en Galicia e Casubia foron decisivas na toma de posición da Igrexa fronte aos idiomas vernáculos destes territorios.

O «pecado orixinal» do galeguismo, segundo expresión de Ferro Ruibal (1990: 350), foi o liberalismo co que compartía tanto o obxectivo (mellorar a situación económica de Galicia) como o inimigo (a Igrexa católica). En Casubia, a clase media formouse a base dos campesiños-propietarios e adquiriu o seu carácter conservador e tradicionalista (Obracht-Prondzyński 2003: 174). A continuada competencia do protestantismo fixo do catolicismo o factor constitutivo da identidade casubia e determinante na decisión de integración no movemento nacional polaco. De maneira que a Igrexa católica foi un aliado natural do movemento nacional casubio co que compartía tanto o obxectivo (a loita pola independencia de Polonia) como o inimigo (o protestantismo e o kulturkampf do Estado prusiano).

O desenvolvemento do nacionalismo galego dentro da tendencia esquerdista agudizou cada vez máis a polarización entre a Igrexa católica e o galeguismo aínda despois da desamortización e da perda por parte da Igrexa dunha posición social. Na última fase do franquismo, cando a Igrexa empezou o distanciamento co réxime ditatorial, situouse, aínda que parcialmente, no mesmo bando que o perseguido galeguismo. No período democrático desapareceron estes vínculos e 
CAstro, O. / M. LiÑEIRA (eds.) (2015): Trama e urda. Contribucións multidisciplinares desde os estudos galegos, Santiago de Compostela, Consello da Cultura Galega. doi:10.17075/tucmeg.2015.

o movemento nacional galego adoitou ser interpretado pola Igrexa como un movemento separatista co que non quería ter nada en común.

Durante moito tempo o movemento casubio careceu dun partido que defendera os seus intereses formando só unhas asociacións e grupos de carácter político-cultural. Os escritores reunidos nestes círculos eran á vez os ideólogos do movemento. Nas súas formulacións, sempre se insistía no valor decisivo da relixión na identidade casubia e no vínculo que a unía coa nacionalidade polaca. Na República Popular de Polonia, o movemento nacional casubio e a Igrexa católica combatían no mesmo bando de oposición ao réxime comunista. Desde o principio da súa actividade, a ACP (primeiro como Asociación Casubia), creada en 1956, colaborou moi estreitamente coa Igrexa. O sistema totalitario de esquerdas instalado en Polonia desde 1944-45 e o seu carácter anticlerical non permitiron a aparición doutra tendencia política que a ACP en Casubia. A estrutura e organización construídas durante estes anos déronlle á ACP o práctico monopolio político en Casubia despois da democratización do país. Aínda hoxe, cando xa apareceron outras formacións políticas en Casubia, é sobre todo a xeración nova da mesma ACP a que cambia esta organización desde dentro (Obracht-Prondzyński 2003: 139). Na nova política da ACP hai cada vez menos sitio para a relixión e a colaboración coa Igrexa, porque desapareceu a comuñón dos obxectivos.

O CVII supuxo un cambio substancial na perspectiva das relacións entre Deus e crentes. A misa converteuse no encontro do Deus-Pai cos seus fillos. A comunicación entre eles debía realizarse na lingua materna para facer esta relación máis íntima. Nun ambiente familiar, a elección da lingua de comunicación debería ser natural e carecer de connotacións políticas. A actitude lingüística da Igrexa católica en Galicia e Casubia parece probar o contrario. $\mathrm{O}$ que na perspectiva conciliar ía servir para afastar a Igrexa do ámbito público, converteuse nunha ferramenta máis para a súa conquista.

\section{BiBLIOGRAFÍA}

BORZYSZKOWSKI, Jan / Jan MORDAWSKI/ Jerzy TREDER (1999): Historia, geografia, język i piśmiennictwo Kaszubów, Gdańsk, Wydawnictwo M. Rożak.

CURROS ENRÍQUEZ, Manuel (1990): Aires da miña terra, Vigo, Xerais.

CHAO REGO, Xosé (1988): Para comprendermos Galicia, Vigo, Galaxia.

FERRO RUIBAL, Xesús (1987): A Igrexa e a lingua galega, Santiago de Compostela, Consello da Cultura Galega.

FERRO RUIBAL, Xesús (1990): «Lingua galega e a relixión», Grial, 107, 335-357.

FERRO RUIBAL, Xesús (2000): «Algúns textos relixiosos galegos anteriores a admisión do galego como lingua litúrxica», en Daniel López Muñoz (coord.), A palabra fai camiño, A Coruña, Asociación Irimia, 43-159. 
CAStro, O. / M. LiÑEIRA (eds.) (2015): Trama e urda. Contribucións multidisciplinares desde os estudos galegos, Santiago de Compostela, Consello da Cultura Galega. doi:10.17075/tucmeg.2015.

FILGUEIRA VALVERDE, Xosé (1969): «Góngora y Galicia», Cuadernos de Estudios Gallegos, V. XXIV, 225-258.

GŁODOWSKI, Bogusław (2006): Duszpasterze Kościoła Katolickiego na Kaszubach w XX wieku (http://www.diecezja.gda.pl/modules.php?name=Content\&pa=showpage\&pid=233) [última consulta: xaneiro, 2013].

GUS (2012): Raport z wyników. Narodowy spis powszechny ludności i mieszkań, Warszawa, Zakład Wydawnictw Statystycznych.

HILFERDING, Aleksaader (1989): Resztki Stowian na południowym wybrzeżu morza Battyckiego, Gdańsk, Zrzeszenie Kaszubsko-Pomorskie.

IGLESIAS, Armindo (2008): Carta da parroquia: Santa Eulalia de Vedra, A Coruña, 378.

LABUDA, Gerard (2007): «Jak Kaszuba z Kaszubą», Tygodnik Powszechny, 7 (http://tygodnik2003-2007.onet.pl/3229,1401027,0,dzial.html) [última consulta: xaneiro, 2013].

LÓPEZ MUÑOZ, Daniel (1989): O idioma da igrexa en Galicia, Santiago de Compostela, Consello da Cultura Galega.

LÓPEZ MUÑOZ, Daniel / Bernardo GARCÍA CENDIÁN (2000): Receptividade do galego na liturxía, Santiago de Compostela, Consello da Cultura Galega.

LOREK, Gottlieb Leberecht (2009): «Charakterystyka Kaszubw znad Leby», en Józef Borzyszkowski (ed.), Niemcy o Kaszubach w XIX wieku, Gdańsk, Instytut Kaszubski w Gdańsku, 37-79.

MANDIANES CASTRO, Manuel (1997): «Antropoloxía política de Galicia», en Xosé Manuel Gil de Berbabé (et al), Artesanía. Sociedade, A Coruña, Hércules Ediciones, 462-490.

MARIÑO PAZ, Ramón (1995): «Notas para a caracterización sociolingüística da Galicia dos séculos XVIII e XIX», Trabe de Ouro, 24, 563-569.

MARIÑO PAZ, Ramón (1998): Historia da lingua galega, Santiago de Compostela, Sotelo Blanco.

OBRACHT-PRONDZYŃSKI, Cezary (2003): W kręgu problematyki kaszubsko-pomorskiej: studia i szkice, Gdańsk-Wejherowo, Muzeum Piśmiennictwa i Muzyki KaszubskoPomorskiej, Istytut Kaszubski.

OBRACHT-PRONDZYŃSKI, Cezary (2007): Kaszubi dzisiaj: kultura-język-tożsamość, Gdańsk, Instytut Kaszubski.

PÉREZ PRIETO, Victorino (1996): A Igrexa oficial non está comprometida co pobo (http://www.aelg.org/resources/centrodoc/members/paratexts/pdfs/autor233/PT_paratext4130.pdf) [última consulta: xaneiro, 2013].

PERSZON, Jan (2005): Kaszubszczyzna $w$ liturgii (http://kaszubski.filmjezus.org.pl/index.php? option=com_content\&task=view\&id=59\&Itemid=51) [última consulta: xaneiro, 2013].

PRYCZKOWSKI, Eugeniusz (sen data a): Kaszubszczyzna w Kościele, manuscrito.

PRYCZKOWSKI, Eugeniusz (sen data b): Komisja Kościelna ZKP (2004-2010) w procesie wchodzenia kaszubszczyzny do liturgii Koscioła, manuscrito.

PRYCZKOWSKI, Eugeniusz (sen data c): «Rodna mowa w liturgii», Miejsca Święte (http:www.ms.ecclesia.org.pl/index.php?option=com_content\&view $=$ article\&id $=620$ ) [última consulta: xaneiro, 2013].

STENKA, Danuta (2012): «Trening z kaszubskiego», Zwierciadło, 5, 82-87.

SYNAK, Brunon (1998): Kaszubska tożsamość: ciagłość i zmiana, Gdańsk, Wydawnictwa Uniwersytetu Gdańskiego. 
CAstro, O. / M. LiÑEIRA (eds.) (2015): Trama e urda. Contribucións multidisciplinares desde os estudos galegos, Santiago de Compostela, Consello da Cultura Galega. doi:10.17075/tucmeg.2015.

SYNAK, Brunon (2011): «Czarno-żółta tożsamość Pomerania, 02/2011 (http://www.spis.kaszubi.pl/ index.php? event= article \&parent_id=19\&menu_id=1) [última consulta: xaneiro, 2013].

SZMAGLIŃSKI, Ireneusz (2010): «Biskup Pelpliński odznaczony honorowym wyróżnieniem "Za Zasługi dla Województwa Pomorskiego"», KAI (http://ekai.pl/ diecezje/pelplinska/x25281/biskup-pelplinski-odznaczony-honorowym-wyroznieniem -za-zaslugi-dla-wojewodztwa-pomorskiego/) [última consulta: xaneiro, 2013].

VILLANUEVA, Carlos (1994): Los villancicos gallegos, La Coruña, Fundación Barrié de la Maza.

XOÁN XXIII (1963): Pacem in Terris (http://www.vatican.va/holy_father/john_xxiii/ encyclicals/ documents/ hf_j-xxiii_enc_11041963_pacem_lt.html ) [última consulta: xaneiro, 2013].

\section{WEBGRAFÍA}

Archidiecezja Gdańska: Duszpasterstwo Kaszubów

(http://www.diecezja.gda.pl/modules.php?name $=$ Content\&pa $=$ showpage\&pid=230)

[última consulta: xaneiro, 2013].

Galicia Dixital: Manifesto polo galego na Igrexa

(http://www.galiciadigital.com/opinion/opinion.3643.php)

[última consulta: xaneiro, 2013].

Gdańskie Seminarium Duchowne: Koło Kaszubskie

(http://www.gsd.gda.pl/?modul=strony\&strona=157)

[última consulta: xaneiro, 2013].

Instituto Galego de Estatística: Datos básicos de la lengua gallega

(http://www.xunta.es/linguagalega/datos_basicos_de_la_lengua_gallega)

[última consulta: xaneiro, 2013].

Kościerzyna, nasze miasto (2005): Kaszubskojęzyczna prasa

(http://koscierzyna.naszemiasto.pl/archiwum/929146,kaszubskojezyczna-prasa,id,t.html)

[última consulta: xaneiro, 2013].

Sacrosanctum Concilium (1963)

(http://www.vicariadepastoral.org.mx/2_vaticano_ii/sacrosanctum_concilium/sacrosanctum_ concilium.pdf)

[última consulta: xaneiro, 2013].

Wyższe Seminarium Duchowne w Pelplinie: Koło Studentów Kaszubów

(http://www.pelplin.home.pl/seminarium/index.php?go=content,kaszuby)

[última consulta: xaneiro, 2013]. 